\title{
Oxidative stress indicators of rabbit breeds in Ibadan, Southwest Nigeria
}

\author{
Olatunji Abubakar Jimoh ${ }^{1,2}$ (D)
}

\begin{abstract}
Background: Within the rabbit population in Southwest of Nigeria, four breeds of rabbits consisting of Fauve de Bourgogne, Chinchilla, British Spot, and New Zealand White were evaluated for their oxidative status, as indices of physiological adaptation for optimal productivity. This investigation was carried out within July and August when least temperature-humidity index (THI) is observed in Ibadan, Southwest Nigeria. Thirty bucks per breed were housed individually and randomly allotted to experimental units. Blood samples were collected from all bucks and serum obtained using standard procedures. Serum oxidative stress indicators assay include total antioxidant capacity, lipid peroxidation, superoxide dismutase (SOD), catalase, and glutathione peroxidase activity was determined using standard procedures.

Results: Results revealed that serum lipid peroxidation, total antioxidant activity, catalase, and glutathione peroxidase were not significantly $(p>0.05)$ affected by the breeds of rabbit. Fauve de Bourgogne, Chinchilla, and New Zealand White had statistically similar serum SOD activity and were significantly $(p<0.05)$ higher than serum SOD activity of British Spot rabbits. This shows that British Spot has the least superoxide anion scavenging ability across the breeds.

Conclusion: The breeds of rabbit assessed have similar oxidant generation capacity and antioxidant production, except British Spot that has the least superoxide scavenging which could increase oxidant accumulation within this breed of rabbit.
\end{abstract}

Keywords: Antioxidant production, Physiology, Pro-oxidant, Rabbit breed, Oxidants generation

\section{Background}

The blood is easily and often influenced by the external environment including feeding practices, ambient temperature, type of shelter, and many other aspects of herd management since they are intimately related to metabolism (Marai and Habeeb 1998). Reactive oxygen species (ROS), the major culprits for causing oxidative stress, are constantly generated in vivo as an integral part of metabolism. ROS may cause oxidative stress when their level exceeds the threshold value. They trigger the progressive destruction of polyunsaturated fatty acids (PUFA), ultimately leading to membrane destruction (Kumar et al. 2011). The highly reactive hydroxyl radical is especially toxic because it can react with

\footnotetext{
Correspondence: abubakarjimoh2011@gmail.com

${ }^{1}$ Animal Physiology Laboratory, Department of Animal Science, University of Ibadan, Ibadan, Oyo State, Nigeria

${ }^{2}$ Agricultural Technology Department, Federal Polytechnic, Ado Ekiti, Ekiti State, Nigeria
}

proteins, polysaccharides, nucleic acids, and polyunsaturated fatty acids and cause alteration of their structure and functions (Daniel et al. 2005). It is widely accepted that mitochondrial respiration is the primary source of reactive oxygen species (Turrens 2003), with $0.2 \%$ of oxygen consumed converted into superoxide in the normal state (St. Pierre et al. 2002). Levels of ROS are determined by production and by the rate of ROS degradation and/or inactivation, an appropriate balance is important for maintaining cellular homeostasis (Jimoh 2016). Although low levels of ROS are essential in many biochemical processes, accumulation of ROS may damage biological macromolecules, i.e., lipids, proteins, carbohydrates, and DNA (Kumar et al. 2011). External factors such as heat, trauma, ultrasound, infections, radiations, toxins, etc., can lead to increase free radicals and other ROS and may lead to oxidative stress (Halliwell et al. 1992). Oxidative stress is considered to play a pivotal role in the pathogenesis of aging and several 
degenerative diseases, such as atherosclerosis, cardiovascular disease, type 2 diabetes and cancer (Storz 2005). The paucity of information exists on oxidative stress indicators of rabbits under climatic conditions of West Africa. It is important to document oxidative indicators in rabbit breeds in Nigeria, especially reports on thermal comfort conditions which could serve as the baseline for interpretations, diagnosis, and evaluating environmental contributions to oxidative stress in the tropics.

\section{Materials and methods}

\section{Experimental site}

The research was carried out at the rabbit unit of Teaching and Research Farm and Animal Physiology Laboratory, Department of Animal Science, both of the University of Ibadan, Ibadan, Nigeria. It is situated in the rainforest agro-ecological zone of Nigeria, between lat. $7^{\circ} 27^{\prime} 18.74^{\prime \prime} \mathrm{N}$ and $7^{\circ} 27^{\prime} 19.17^{\prime \prime} \mathrm{N}$ and long. $3^{\circ} 53^{\prime}$ 13.98" E and 3 $3^{\circ} 53^{\prime} 32.69^{\prime \prime} \mathrm{E}$.

\section{Experimental animals, design, and management}

Four exotic breeds of rabbit consisting of Fauve de Bourgogne, Chinchilla, British Spot, and New Zealand White were used for the study. At the commencement of the trial, animals were confirmed to be of good health status, without abnormalities, and conform to the breed and/or age group categorization. Thirty bucks per breed were used, animals were housed individually, and allotted randomly into experimental units in a completely randomized design. The animals were fed $5 \%$ of their body weight, with diets containing crude protein $17.05 \%$, digestible energy $2592.06 \mathrm{Kcal} / \mathrm{kg}$, crude fiber $10.02 \%$, calcium $0.45 \%$, and phosphorus $0.21 \%$. Freshwater was available to the animals always. Other routines and periodic management practices necessary for rabbit production were carried out. This experiment was carried out when least Temperature Humidity Index is observed in the study area (within July and August), which depicts the highest thermal comfort in the study area (Jimoh and Ewuola 2018). Blood samples were collected from all bucks through the ear vein into plain sample bottles and were centrifuged at $3000 \mathrm{rpm}$ for $15 \mathrm{~min}$ and supernatant separated as serum.Serum biochemical constituents were determined using spectrophotometric procedure; total protein, glucose, total cholesterol, sodium, chloride, phosphorus, magnesium, and potassium contents of the samples using commercial assay kits.

Serum oxidative stress indicators assay include total antioxidant capacity, lipid peroxidation, superoxide dismutase, catalase, and glutathione peroxidase activity.

Determination of serum total antioxidant capacity activities was carried out according to the reactive mixture containing $0.5 \mathrm{~mL}$ of a $(10 \mathrm{mmol} / \mathrm{L})$ Na-Benzoate, 0.2 $\mathrm{mL}$ of $\mathrm{H}_{2} \mathrm{O}_{2}(10 \mathrm{mmol} / \mathrm{L}), 0.49 \mathrm{ml}$ of phosphate buffer
( $100 \mathrm{mmol} / \mathrm{L}, \mathrm{pH}=7.4)$ (prepared by mixing $19.5 \mathrm{ml}$ of $\mathrm{KH}_{2} \mathrm{PO}_{4}(100 \mathrm{mmol} / \mathrm{L})$ with $80.5 \mathrm{ml}$ of $\mathrm{Na}_{2} \mathrm{HPO}_{4}(100$ $\mathrm{mmol} / \mathrm{L}$ ), then adjusted the $\mathrm{pH}$ to 7.4 and $0.2 \mathrm{ml}$ of Fe-EDTA complex $(2 \mathrm{mmol} / \mathrm{L})$ (prepared freshly by mixing equal volumes of EDTA $(2 \mathrm{mmol} / \mathrm{L})$, and ammonium ferrous sulfate $(2 \mathrm{mmol} / \mathrm{L})$, then left at $25^{\circ} \mathrm{C}$ for $60 \mathrm{~min}$. Ten microliters of the blood serum were added to the latter reactive mixture and were incubated at $37^{\circ} \mathrm{C}$ for $60 \mathrm{~min}$. Finally, $1 \mathrm{ml}$ glacial acetic acid $(20 \mathrm{mmol} / \mathrm{L})$ and $1 \mathrm{ml}$ thiobarbituric acid $(0.8 \% w / v$ in $100 \mathrm{ml}$ of $50 \mathrm{mmol} / \mathrm{L} \mathrm{NaOH}$ ) were added, and the absorbance at $532 \mathrm{~nm}$ was measured spectrophotometrically after incubation at $100^{\circ} \mathrm{C}$ for $10 \mathrm{~min}$. Total antioxidant capacity was calculated according to the following formula:

$$
\text { TAcapacity }(\mathrm{mmol} / \mathrm{L})=\mathrm{CUA}(\mathrm{K}-\mathrm{A}) /(\mathrm{K}-\mathrm{UA})
$$

Where CUA (mmol/L); concentration of uric acid.

$K$ : absorbance of control (K1 - K0)

$A$ : absorbance of the sample (A1 - A0).

UA: absorbance of uric acid solution (UA1-UA0)

(Koracevic et al. 2001)

The assay for lipid peroxidation; the reaction mixture in a total volume of $3.0 \mathrm{ml}$ contained $1.0 \mathrm{ml}$ serum and $1.0 \mathrm{ml}$ of TCA (0.67\%). All the test tubes were placed in a boiling water bath for a period of $45 \mathrm{~min}$. The tubes were shifted to the ice bath and then centrifuged at $2500 \mathrm{rpm}$ for $10 \mathrm{~min}$. The amount of malondialdehyde (MDA) formed in each of the samples was assessed by measuring the optical density of the supernatant at 532 nm (Ohkawa et al. 1979).

Superoxide dismutase (SOD); $2.1 \mathrm{ml}$ of $50 \mathrm{mM}$ buffer, $0.02 \mathrm{ml}$ of enzyme source, and $0.86 \mathrm{ml}$ of distilled water. The reaction is initiated with $0.02 \mathrm{ml}$ of $10 \mathrm{mM}$ pyrogallol and change in absorbance monitored at $420 \mathrm{~mm}$. One unit of SOD is defined as that amount of enzyme required to inhibit to auto-oxidation of pyrogallol by $50 \%$ in the standard assay system of $3 \mathrm{ml}$. The specific activity is expressed as unit/min/mg protein (Soon and Tan 2002).

Glutathione peroxidase activity; $0.5 \mathrm{ml}$ of $0.4 \mathrm{M}$ buffer, $\mathrm{pH} 7.0,0.2 \mathrm{ml}$ enzyme source, $0.2 \mathrm{ml}$ of $2 \mathrm{mM} \mathrm{GSH}$, and $0.1 \mathrm{ml}$ of $0.2 \mathrm{mM} \mathrm{H}_{2} \mathrm{O}_{2}$ were added and incubated at room temperature for $10 \mathrm{~min}$ along with the control tube containing all reagents except enzyme source. The reaction arrested by adding $0.5 \mathrm{ml}$ of $10 \%$ TCA, centrifuged at $4000 \mathrm{rpm}$ for $5 \mathrm{~min}$, and the GSH content in $0.5 \mathrm{ml}$ of supernatant was estimated. The activity expressed as microgram of GSH consumed/min/mg protein (Rotruck et al. 1973).

Catalase activity; the assay system contains $1.9 \mathrm{ml}$ of $0.05 \mathrm{M}$ buffer, $\mathrm{pH} 7.0$, and $1.0 \mathrm{ml}$ of $0.059 \mathrm{M} \mathrm{H}_{2} \mathrm{O}_{2}$. The reaction is initiated by addition of $0.1 \mathrm{ml}$ enzyme source. The decrease in absorbance is monitored at $1 \mathrm{~min}$ 
interval for $5 \mathrm{~min}$ at $240 \mathrm{~nm}$, and activity is expressed as nanomoles of $\mathrm{H}_{2} \mathrm{O}_{2}$ decomposed $/ \mathrm{min} / \mathrm{mg}$ protein (Beers and Sizer 1952).

\section{Statistical analysis}

Data obtained in this study was subjected to one-way analysis of variance of general linear procedure (SAS Institute Inc 2003), significant effects were detected with a confidence level of 95\%, and New Duncan's multiple range test of same software was used to separate means.

\section{Results}

The serum biochemical indices of four rabbit are presented in Table 1. All parameters assessed were not significantly $(p>0.05)$ affected by the breed of the rabbits. The result obtained showed that serum biochemicals were not affected by breed differences, indicative of similar physiological status across the breeds. The serum lipid peroxidation of four breeds of rabbits at least THI in Ibadan is shown in Fig. 1. Lipid peroxidation was not significantly $(p>0.05)$ affected by the breeds of rabbit. However, British Spot had apparently the highest values among the breeds. Serum total antioxidant activity of the rabbits was not influenced significantly by breed differences as revealed in Fig. 2. Apparently, British Spot had the highest value among the breed for total antioxidant activity. Serum superoxide dismutase activity was significantly $(p<0.05)$ different across the breeds as shown in Fig. 3. Fauve de Bourgogne, Chinchilla, and New Zealand White had statistically similar serum SOD activity and were significantly $(p<0.05)$ higher than British Spot rabbits. Serum catalase activity of New Zealand White rabbits was apparently highest compared with other breeds, but no significant $(p>0.05)$ difference was observed across the breeds as shown in Fig. 4. Serum glutathione peroxidase was not significantly affected by the breeds of rabbits as shown in Fig. 5.

\section{Discussion}

The serum biochemical indices were assessed at least in Temperature Humidity Index which is indicative of thermal comfort. The obtained result showed that serum biochemical indices were not affected by breed differences, indicative of similar physiological status across the breeds. The animals had only one source of variation (breed), and the environmental conditions were indicative of thermal comfort in the study area. It can be suggested that the rabbit breeds have similarities in physiology under normal conditions.

The ranges of obtained values were in agreement with values reported by Ahemen et al. (2013), Odetola et al. (2012), and Ewuola et al. (2012), and were within the normal range of biochemical values as reported by Mitruka and Rawnsley (1977) and Duncan and Prasse (1986).

The decrease in plasma glucose could be due to the increase in glucose utilization to produce more energy for greater muscular expenditure required for high respiratory activity and/or the marked dilution of blood and body fluids as a whole caused by an increase in water consumption (Habeeb et al. 1992). Okab et al. (2008) reported that plasma total protein, globulins, total lipids, and cholesterol of New Zealand White rabbits were increased during the summer season and suggest that exposure of New Zealand rabbits to hot environmental conditions may have adverse physiological effects. Decrease in serum total proteins may be due to decrease in feed nitrogen intake which occurs under heat-stress conditions (Marai et al. 2007), decrease of protein synthesis as a result of the depression of anabolic hormonal secretion, and/or dilution of plasma proteins caused by the increase of the water consumed (El-Masry and Habeeb 1989). Total lipids and cholesterol were affected by the season and cholesterol were increased during the summer season in rabbit (Okab et al. 2008) and in dairy cattle (El-Masry and Marai 1991). They attributed these changes to variations in thyroidal activity at different seasons, as exposure to low environmental temperature stimulates the secretion of thyroxine. Thyroid hormones stimulate cholesterol synthesis as well as the hepatic mechanisms that remove cholesterol from the circulation. Cholesterol is the precursor in the

Table 1 Serum biochemistry of four exotic breeds of rabbit

\begin{tabular}{llllll}
\hline & Fauve de Bourgogne & Chinchilla & British Spot & New Zealand White & SEM \\
\hline Glucose, $\mathrm{mmol} / \mathrm{L}$ & 61.82 & 75.65 & 60.00 & 66.20 & 3.93 \\
Total Protein, g/L & 54.8 & 60.8 & 60.9 & 51.2 & 2.80 \\
Cholesterol, $\mathrm{mmol} / \mathrm{L}$ & 1.32 & 1.59 & 1.84 & 1.68 & 0.16 \\
Magnesium, $\mathrm{mmol} / \mathrm{L}$ & 3.77 & 2.61 & 3.72 & 3.06 & 0.07 \\
Phosphorus, $\mathrm{mmol} / \mathrm{L}$ & 2.10 & 2.11 & 2.01 & 2.11 & 0.09 \\
Sodium, $\mathrm{mmol} / \mathrm{L}$ & 114.56 & 120.89 & 117.87 & 110.23 & 5.66 \\
Potassium, $\mathrm{mmol} / \mathrm{L}$ & 52.78 & 39.26 & 37.04 & 45.79 & 5.92 \\
Chloride, $\mathrm{mmol} / \mathrm{L}$ & 50.94 & 54.19 & 55.27 & 54.05 & 1.59 \\
\hline
\end{tabular}




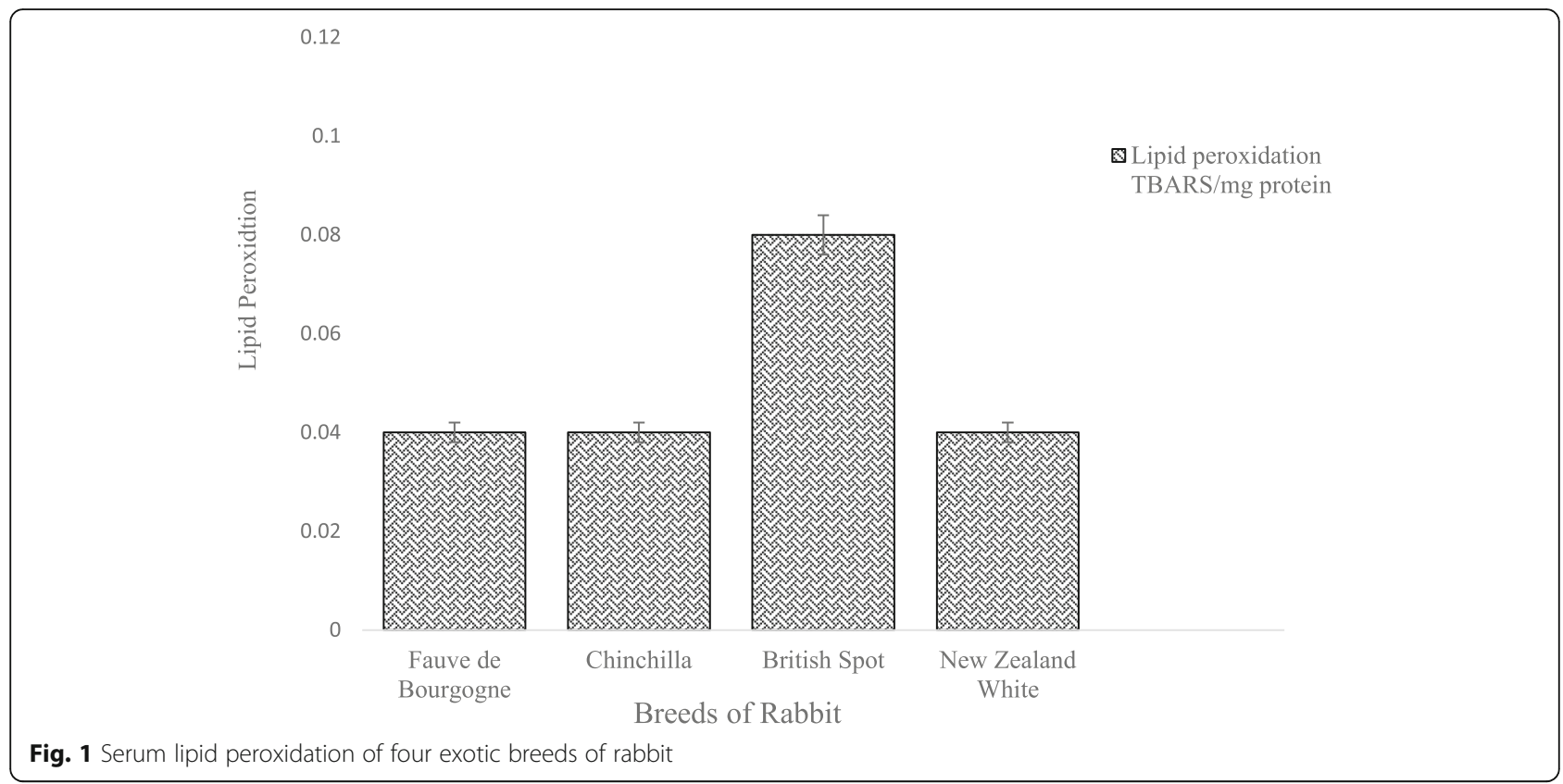

biosynthesis of sex hormones. The decline in plasma cholesterol level may be because the rate of the later process exceeds that of the former, and the plasma cholesterol level drops before the metabolic rate rises (Guyton 1981). The decrease in $\mathrm{Na}+$ and $\mathrm{K}+$ are related to increases in loss of urinary $\mathrm{Na}+$ and loss of skin $\mathrm{K}+$ (Kumar et al. 2011). Enhanced heat dissipation during heat stress may also lead to electrolyte losses through sweat, saliva, polypnea, and urine. This may lead to falling in plasma $\mathrm{Na}+, \mathrm{K}+$, and $\mathrm{Cl}-$ concentration (Coppock et al. 1982). Scheneider et al. (1984) reported that heat stress in lactating dairy cows caused a significant loss of serum $\mathrm{Na}+$ and $\mathrm{K}+$. West (1999) also reported a similar fall in serum electrolyte concentration in dairy cows subjected to heat stress

British Spot rabbit had apparently highest values among the breeds; this suggests low antioxidant defense against free radical species metabolites, thus predisposing the animals to oxidative stress. Serum total antioxidant activity of the rabbits was not influenced significantly by breed differences. Similarly, British Spot had the highest value among the breeds for total antioxidant activity. This suggests that the lipid peroxidation in British Spot may be due to the deficit in certain free

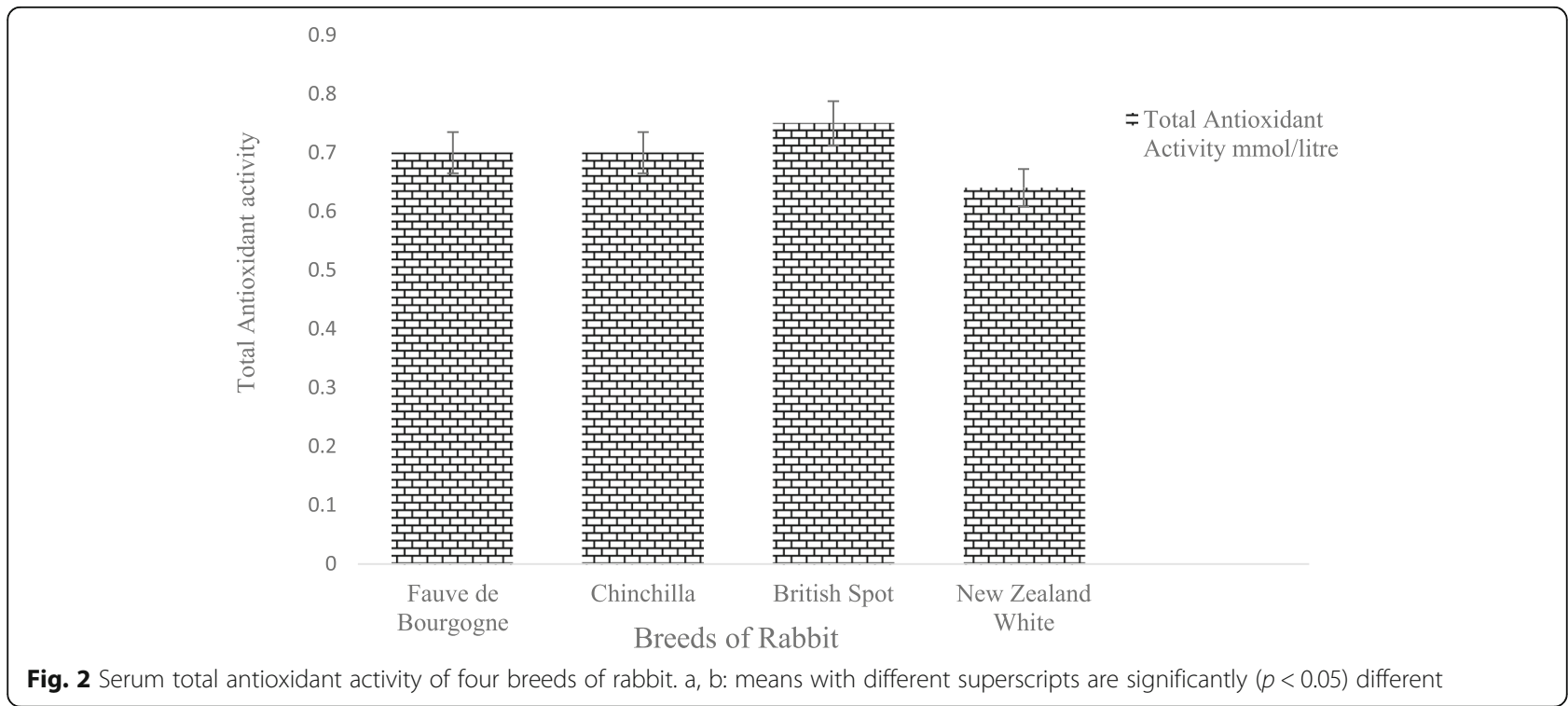




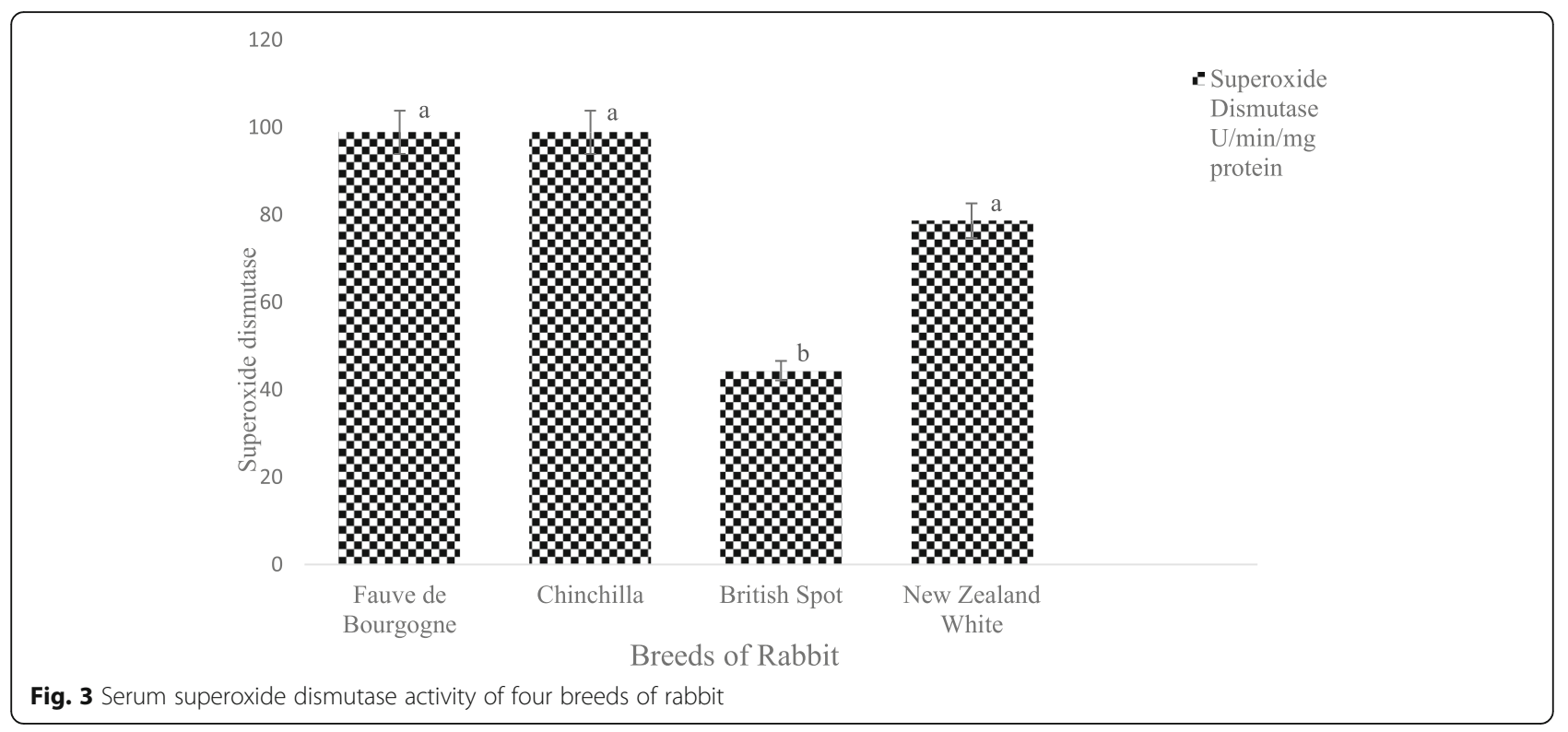

radical species metabolites scavenger (antioxidant) in the serum of the animals, but the other substrates elimination were high due to the activity of their systemic scavenger (antioxidant). Lipid peroxidation is a result of the combined effect of different free radicals and metabolites. The elimination of certain free radical/metabolites may not reduce the precipitation of the others that are active. Total antioxidant activity measures the combined activity of enzymatic and non-enzymatic antioxidants which act on specific substrates: superoxide dismutase (superoxide anion), catalase, and glutathione peroxidase (hydrogen peroxide). High total antioxidants activity could be due to the activity of one or more component antioxidants. Fauve de Bourgogne, Chinchilla, and New Zealand White had statistically similar serum SOD activity and were $(p<0.05)$ higher than British Spot rabbits. This confirms the earlier suggestions that British Spot has low superoxide dismutase anion (free radical species) scavenging ability, and the accumulations of the superoxide anion account for high-lipid peroxidation and subsequent oxidative stress in the animals. The catalase and glutathione peroxidase activity of British Spot was similar, though values were apparently $(p>0.05)$ lower than New Zealand White, but were $(p>0.05)$ higher than Chinchilla and Fauve de Bourgogne.

The body's total antioxidant capacity serves to protect cells from excess production of ROS (Bloomer and Fisher-Wellman 2008; Brennan and Kantorow 2008). The reactive oxygen species contribute to an intensified synthesis of antioxidant enzymes in tissues and hence

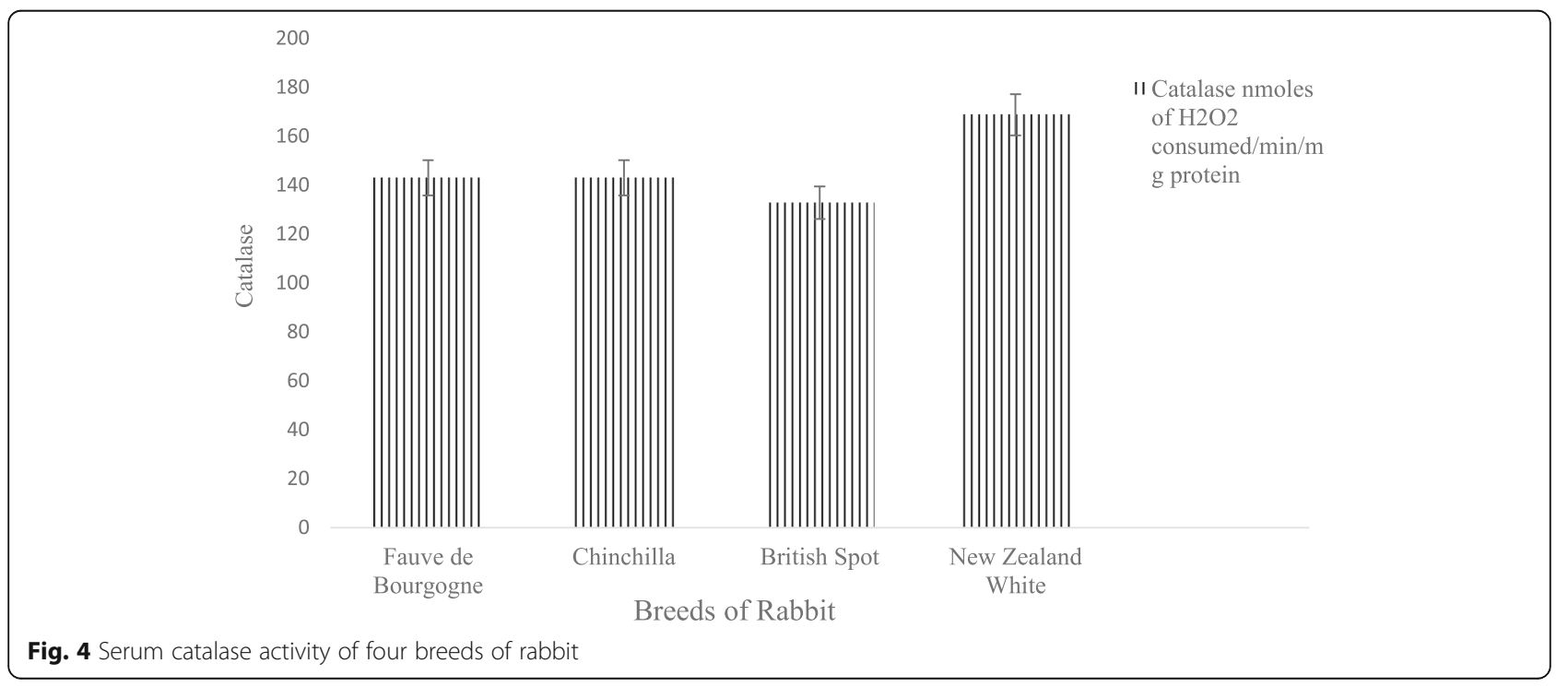




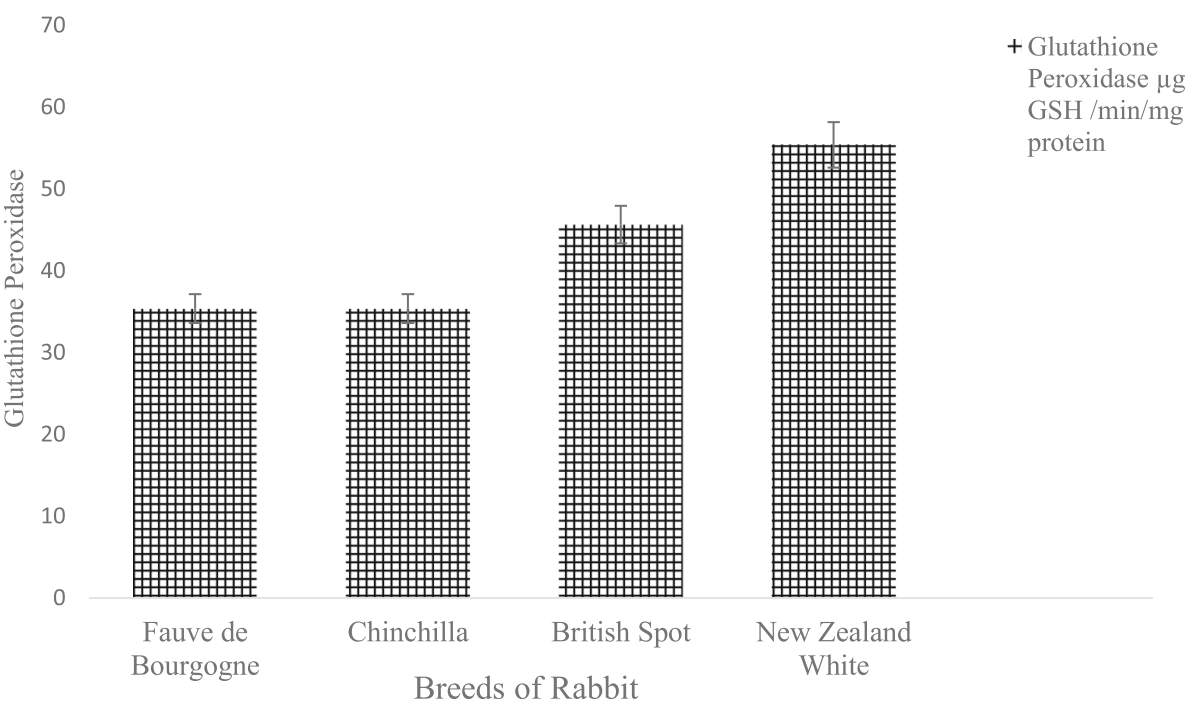

Fig. 5 Serum glutathione peroxidase activity of four breeds of rabbit

their elevated activity may be a manifestation of adaptation mechanisms in response to oxidative stress. A decreased activity of antioxidant enzymes or a decreased non-enzymatic antioxidant concentration may be caused by their intensified utilization in protection against oxidative tissue damage (Seven et al. 2001).

The great majority of the energy released under basal conditions is used by the cell for the maintenance of the $\mathrm{Na}+\mathrm{K}+$ dependent ATP-ase activity. This increased the use of ATP associated with the intensification of oxygen consumption by the oxidative phosphorylation pathway that generates reactive oxygen species (Sies 1997).

\section{Conclusion}

The study reveals that the four breeds of rabbit have similar oxidative status. However, British Spot has low superoxide dismutase scavenging ability and could pose danger to lipid peroxidation at high metabolic or physiological conditions. This serves as reference values for oxidative status and interpretation of different condition for the rabbit breeds.

\section{Abbreviations \\ GSH: Glutathione; MDA: Malondialdehyde; PUFA: Polyunsaturated fatty acids; ROS: Reactive oxygen species; RPM: Revolution per minute; SEM: Standard error of mean; SOD: Superoxide dismutase; TBARS: Thiobarbituric acid reactive substances; TCA: Trichloroacetic acid; THI: Temperature-humidity index}

\section{Acknowledgments}

The authors are grateful to the management and staff of the Rabbitry Unit, Teaching and Research Farm, University of Ibadan, for their assistance in providing animals and housing for this work. Also, Dr. Ajayi Babajide Oluwaseun of Biochemistry Department, BOWEN University, Iwo, Osun State, Nigeria is appreciated for his technical assistance in oxidative status assay procedures and chemicals used.

\section{Funding}

This research did not receive any specific grant from any funding agency in the public, commercial or not-for-profit sector.

\section{Availability of data and materials}

The datasets used and/or analyzed during the current study are available from the corresponding author on reasonable request.

\section{Author's contributions}

OAJ designed, carried out the field work, and supervised the study, carried out the statistical analysis, and wrote the manuscript. The author read and approved the final manuscript.

\section{Author's information}

Jimoh, Olatunji Abubakar Ph.D. (Registered Animal Scientist; Nigerian Institute of Animal Science)Lecturer and consultant,

Animal physiology and bioclimatology,

Department of Agricultural Technology, Federal Polytechnic Ado Ekiti, Ekiti State. Nigeria.

Email: abubakarjimoh2011@gmail.com

\section{Ethics approval and consent to participate}

The study was undertaken with approval from the institutional ethics committee for care and use of animal for research of the host institution.

\section{Consent for publication}

Not applicable

\section{Competing interests}

The author declares that he has no competing interests.

\section{Publisher's Note}

Springer Nature remains neutral with regard to jurisdictional claims in published maps and institutional affiliations.

Received: 26 November 2018 Accepted: 25 March 2019

Published online: 11 April 2019

\section{References}

Ahemen T, Abu AH, Gbor V (2013) Haematological and serum biochemical parameters of rabbits fed varying dietary levels of water spinach Ipomoea aquatic leaf meal. Adv Appl Sci Res 42:370-373

Beers RF, Sizer IW (1952) A spectrophotometric method for measuring the breakdown of hydrogen peroxide by catalase. J Biol Chem 195:133-140 
Bloomer RJ, Fisher-Wellman KH (2008) Blood oxidative stress biomarkers: influence of sex, exercise training status, and dietary intake. Gend Med 5 : $218-228$

Brennan LA, Kantorow M (2008) Mitochondrial function and redox control in the aging eye: role of MsrA and other repair systems in cataract and macular degenerations. Exp Eye Res 88:195-203

Coppock CE, Grant PA, Portzer SJ (1982) Lactating dairy cow responses to dietary sodium, chloride, bicarbonate during hot weather. J Dairy Sci 65:566

Daniel C, Chihhao C, Ting-Chieh H (2005) Free Radical the Body Killer. National Taichung Second Senior High School, pp 1-7 Retrieved from: www.pdffactory.com

Duncan JR, Prasse KW (1986) Veterinary Laboratory Medicine, 2nd edn. lowa State University Press, USA, p 2

El-Masry KA, Habeeb AA (1989) Thyroid function in lactating Friesian cows and water buffaloes under winter and summer Egyptian conditions. Proceedings of 3rd Egyptian-British Conference on Animal, Fish and Poultry Production, Alexandria. Egypt 2:613-620

El-Masry KA, Marai IFM (1991) Comparison between Friesians and water buffaloes in growth rate, milk production and some blood constituents during winter and summer conditions of Egypt. Anim Prod 53:39-43

Ewuola EO, Jimoh OA, Atuma OV, Soipe OD (2012) Haematological and serum biochemical response of growing rabbits fed graded levels of Moringa oleifera leaf meal. World Rabbit Science Association Proceedings 10th World Rabbit Congress - September 3-6, 2012- Sharm El- Sheikh -Egypt, pp 679683

Guyton AC (1981) Lipid metabolism. In: Textbook of Medical Physiology, 6th edn. W. B. Saunders Company, Philadelphia, pp 849-860

Habeeb AA, Marai IFM, Kamal TH (1992) Heat stress in farm animals and the environment ed. C. J. C. Philips and D. Piggins. CAB International, Wallingford, pp 27-47

Halliwell B, Gutteridge JMC, Cross CE (1992) Free radicals, antioxidants and human diseases: Where are we now? J Lab Clin Med 1196:598-620

Jimoh OA (2016) Assessment of the oxidative stress markers and reproductive performance of four exotic breeds of rabbit in Ibadan. Ph.D. Thesis, University of Ibadan, Ibadan, Nigeria, pp 45-72

Jimoh OA, Ewuola EO (2018) Thermophysiological traits in four exotic breeds of rabbit at least temperature-humidity index in humid tropics. J Basic Appl Zool 79(18):31-39 https://doi.org/10.1186/s41936-018-0031-9

Koracevic D, Koracevic G, Djordjevic V, Andrejevic S, Cosic V (2001) Method for the measurement of antioxidant activity in human fluids. J Clin Pathol 54: 356-361

Kumar S, Ajeet BVK, Meena K (2011) Review: Effect of heat stress in tropical livestock and different strategies for its amelioration. J Stress Physiol Biochem $7(1): 45-54$

Marai IFM, El-Darawany AA, Fadiel A, Abdel-Hafez MAM (2007) Physiological traits as affected by heat stress in sheep-a review. Small Rumin Res 71:1-12

Marai IFM, Habeeb AA (1998) Adaptability of Bos taurous cattle under hot arid conditions. Ann Arid Zone 37(3):253-281

Mitruka BM, Rawnsley HM (1977) Clinical Biochemical and Haematological Reference values in normal experimental animals. Masson Publishing, New York, pp 21-64

Odetola MO, Ewuola EO, Adu AO (2012) Haematology, serum biochemistry and organ histopathology of rabbits fed graded levels of whole Kenaf seed meal. Int J Agric Res 72:86-92

Ohkawa H, Ohishi N, Yagi K (1979) Assay for lipid peroxides in animal tissues by thiobarbituric acid reaction. Anal Biochem 95:351-358

Okab AB, El-Banna SG, Koriem AA (2008) Influence of environmental temperatures on some physiological and biochemical parameters of New Zealand rabbit males. Slovak J Anim Sci 41(1):12-19

Rotruck JT, Pope AL, Ganther HE, Swanson AB, Hafeman DC, Hoekstra WG (1973) Selenium: biochemical roles as a component of glutathione peroxidase. Science 179:588-590

SAS Institute Inc (2003) SAS/STAT User's guide, version 8 for windows. SAS Inst. Inc, Cary

Scheneider DL, Beede DK, Wilcox CJ, Collier RJ (1984) Influence of dietary sodium bicarbonate and potassium carbonate on heat stressed lactating dairy cows. J Dairy Sci 67:2546-2553

Seven R, Gelisgen R, Seven A, Erbil Y, Bozbora A, Burcak G (2001) Influence of propylthiouracil treatment on oxidative stress and nitric oxide in Basedow disease patients. J Toxicol Environ Health A 62:495-503

Sies H (1997) Oxidative stress. Oxidants and antioxidants. Exp Physiol 82:291295
Soon YY, Tan BKH (2002) Evaluation of the hypoglycemic and anti-oxidant activities of Morinda officinalis in streptozotocininduced diabetic rats. Singap Med J 43:77-85

St. Pierre J, Buckingham JA, Roebuck SJ, Brand MD (2002) Topology of superoxide production from different sites in the mitochondrial electron transport chain. J Biol Chem 277:44784-44790

Storz P (2005) Reactive oxygen species in tumor progression. Front Biosci 10: 188196

Turrens JF (2003) Mitochondrial formation of reactive oxygen species. J Physiol 552:335-344

West JW (1999) Nutritional strategies for managing the heat-stressed dairy cows. J Anim Sci 77(2):21-35

\section{Submit your manuscript to a SpringerOpen ${ }^{\circ}$ journal and benefit from:}

- Convenient online submission

- Rigorous peer review

- Open access: articles freely available online

- High visibility within the field

- Retaining the copyright to your article

Submit your next manuscript at $>$ springeropen.com 